\title{
The evolution of inquilinism, host-plant use and mitochondrial substitution rates in Tamalia gall aphids
}

\author{
D. G. MILLER III* \& B. CRESPI† \\ *Department of Biological Sciences, California State University-Chico, Chico, CA, USA and Department of Biology, Trinity University, San Antonio, TX, USA \\ $\dagger$ Behavioural Ecology Research Group, Department of Biological Sciences, Simon Fraser University, Burnaby BC, Canada
}

Keywords:

inquilinism;

host-plant use;

phylogeny;

Tamalia aphids.

\begin{abstract}
We used mitochondrial DNA data to infer phylogenies for 28 samples of gallinducing Tamalia aphids from 12 host-plant species, and for 17 samples of Tamalia inquilinus, aphid 'inquilines' that obligately inhabit galls of the gall inducers and do not form their own galls. Our phylogenetic analyses indicate that the inquilines are monophyletic and closely related to their host aphids. Tamalia coweni aphids from different host plants were, with one exception, very closely related to one another. By contrast, the T. inquilinus aphids were strongly genetically differentiated among most of their host plants. Comparison of branch lengths between the $T$. coweni clade and the $T$. inquilinus clade indicates that the $T$. inquilinus lineage evolves 2.5-3 times faster for the cytochrome oxidase I gene. These results demonstrate that: (1) Tamalia inquilines originated from their gall-inducing hosts, (2) communal (multifemale) gall induction apparently facilitated the origin of inquilinism, (3) diversification of the inquilines has involved rapid speciation along host-plant lines, or the rapid evolution of host-plant races, and (4) the inquilines have undergone accelerated molecular evolution relative to their hosts, probably due to reduced effective population sizes. Our findings provide insight into the behavioural causes and evolutionary consequences of transitions from resource generation to resource exploitation.
\end{abstract}

\section{Introduction}

Understanding how different groups of insects and other organisms have diversified requires the recognition of convergent patterns that connect particular aspects of the biology of the group to their evolutionary dynamics (e.g. Mitter et al., 1988; Farrell \& Mitter, 1990; Mitter \& Farrell, 1991; Gaston et al., 1992). For example, most cases of cospeciation between phytophagous insects and their host plants, or between phytophagous insects and their enemies, involve relatively intimate ecological interactions, such as specialized plant chemistry (e.g. Farrell \& Mitter, 1998), obligate mutualism or parasitism (Herre et al., 1996; Machado et al., 1996; Ikino et al.,

Correspondence: B. Crespi, Behavioural Ecology Research Group, Department of Biological Sciences, Simon Fraser University, Burnaby BC V5A 1S6, Canada.

Tel.: 604291 3533; fax: 604291 3496;

e-mail: crespi@sfu.ca
2001; Lopez-Vaamonde et al., 2001), gall induction (Ronquist \& Nylin, 1990; Burckhardt \& Basset, 2000) and a high degree of specialization to a particular host (e.g. Roderick, 1997; Roderick \& Metz, 1997; Ikino et al., $2001)$. By contrast, frequent expansion and contraction of host-plant ranges is apparently more common in insect groups that exhibit less complex forms of ecological interaction (e.g. Janz \& Nylin, 1998; Jones, 2001). The evolution of 'host-races', forms exhibiting partial genetic differentiation among host-plant species (Abrahamson et al., 1994; Bush \& Smith, 1997; Drès \& Mallett, 2002), appears to represent one of the main routes to diversification in phytophagous insects. However, the circumstances that give rise to host races, rather than a single panmictic and polyphagous species, are as yet poorly understood (Berlocher \& Feder, 2002; Drès \& Mallett, 2002).

Diversification often involves transitions into new adaptive zones. Such transitions take place rarely, due to the magnitude of the evolutionary change required, 
but their macroevolutionary consequences are large because adaptive radiation will commonly ensue (Mitter et al., 1988; Price \& Roininen, 1993; Schluter, 2000). One of the more common forms of transition is the adoption of an obligately parasitic or inquiline lifestyle. Transitions to parasitism (which involves harm to the host) or inquilinism (which, by our definition here, does not) may coincide with speciation events or, alternatively, may entail direct anagenetic transformation. Evidence from some taxa suggests that this type of transition can be facilitated by host-plant shifts (Akimoto, 1988a,b, 1989; Pellmyr et al., 1996) and a close evolutionary relationship to the exploited form (e.g. Carpenter et al., 1993; Lowe \& Crozier, 1997), or it may involve sympatric speciation (Buschinger, 1990; Bourke \& Franks, 1991). Moreover, the adoption of parasitism may result in accelerated rates of molecular evolution, perhaps due to reduced effective population sizes (Dowton \& Austin, 1995; Page et al., 1998; Castro et al., 2002), and it may engender bursts of speciation and diversification (Price, 1980). Additional case studies that combine phylogenetic with ecological and behavioural information are required, however, before convergent patterns in the causes and consequences of such transitions can be identified.

The purpose of this paper is to analyse the diversification of Tamalia galling aphids and their non-galling inquilines, in relation to their patterns of host-plant use. To do so, we use molecular-phylogenetic information on the gallers and inquilines collected from the different host-plant species of Arctostaphylos, Comarostaphylis and Arbutus that each of them inhabits. In particular, we address two main questions. First, what is the evolutionary relationship between the host aphids and their inquilines, and how did the inquilines originate? Secondly, how have the hosts and inquilines each diversified in host-plant use, and do they constitute a small number of polyphagous species, or a larger number of monophagous species or host-plant races?

\section{Methods}

\section{Life history of Tamalia aphids}

The genus Tamalia Baker (Tribe Phyllaphidini, Subfamily Drepanosiphinae, Family Aphididae, Order Homoptera) comprises four described species and at least three undescribed species, all in North America and primarily in xeric or boreal habitats (Remaudière $\delta$ Remaudière, 1997; Miller \& Sharkey, 2000; Von Dohlen \& Moran, 2000). All known host plants are of the subfamily Arbuteae, family Ericaceae. All described Tamalia are found on Arctostaphylos spp.; one novel species studied here is reported from Arbutus and another is from Comarostaphylis. These constitute the first records of Tamalia from any genus other than Arctostaphylos. Inquiline Tamalia are so far known only from galls on Arctostaphylos spp.

\section{Tamalia coweni}

The life history of $T$. coweni has been described for populations at the contact zone of the host plants Arctostaphylos viscida and A. patula in the Sierra Nevada, California (Miller, 1998a)(Fig. 1). On A. viscida, the stem mother aphid emerges from the overwintering egg between late April and early June to initiate a gall. During initiation, the gall is open and vulnerable to intrusion; we refer to this stage as the early-phase gall (Mani, 1964). Stem mothers readily share gall space communally and tolerate the heterospecific T. inquilinus (Miller, 1998a,b; Miller \& Sharkey, 2000). In the trophicphase gall, the stem mother continues to induce growth and closure of the gall tissue around her. The stem mother produces a series of offspring parthenogenetically, including males, mating females and, when conditions are favourable, winged parthenogenetic females (Fig. 1). Subsequently, the now mature-phase gall dries and splits open, allowing release of the offspring, all of which complete their fourth and final moult outside the gall before dispersing aerially. Males and mating females, both of which are winged, then disperse and mate elsewhere, typically over the tops of the host plant; thus, a degree of spatial reproductive isolation is achieved and may suppress gene flow among different host-plant populations. The life cycle is completed by July to early August with the oviposition of overwintering eggs by the mating female.

The life cycle of $T$. coweni on A. patula differs from that on $A$. viscida in two important respects: (1) it is delayed a full month, so that stem mothers appear in late May and the life cycle is completed by late August-September; (2) on $A$. patula, the tissue susceptible to gall induction is more widely distributed on the host plant, with the result that stem mothers more commonly produce an additional generation of dispersers and gall-inducers on A. patula. Despite the phenological difference between $T$. coweni life cycles on these two host plants, limited gene flow may occur between $A$. viscida and $A$. patula, as winged females emerging from galls readily larviposit on non-natal host plants under experimental conditions (D. Miller, unpublished data).

\section{Tamalia inquilinus}

The life history of T. inquilinus (Miller \& Sharkey, 2000) is incompletely known, but first-instar stem mothers can invade galls of $T$. coweni during both the early and mature phases of gall growth (Fig. 1). In this respect, the window of opportunity available to inquilines is narrower than that of gall-inducers, which can induce galls as long as suitable host-plant tissues are still growing. Maturephase galls support higher numbers of inquilines than do early or trophic-phase galls. Inquilines begin parthenogenetic reproduction upon reaching adulthood in the host gall. The great majority of offspring produced are 
Fig. 1 Life histories for Tamalia coweni and T. inquilinus. Life cycles are drawn in parallel, with $T$. coweni on the inside and T. inquilinus on the outside of the diagram. In T. coweni, the stem mother induces a gall on the host plant, manzanita (Arctostaphylos spp.), before producing males and mating females, which disperse and mate after emerging from the gall to complete the cycle. The inquiline can enter the host gall at either the early or mature phases of gall elaboration, to reproduce alongside the host aphid, yielding males and mating females.

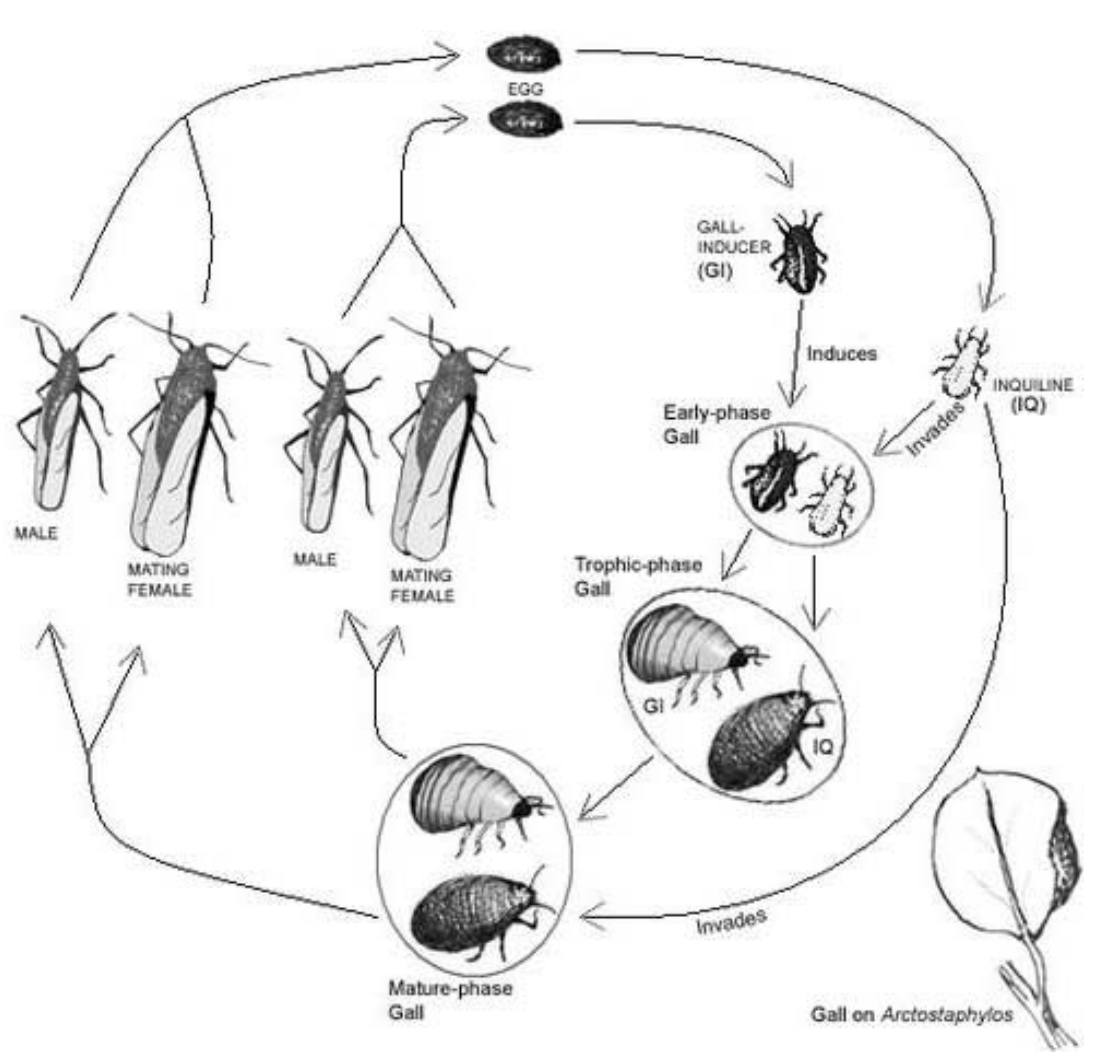

males and mating females, but winged asexual females occasionally appear as well. As winged females are relatively rare, $T$. inquilinus may achieve substantially less dispersal than does T. coweni. Inquilines can persist in mature-phase galls well after the gall-inducers have completed their life cycle. Like the host aphids, male and mating female inquilines are both winged and presumably disperse aerially before mating, probably in the vicinity of the host plant.

\section{Collection}

Tamalia coweni gall-forming aphids and their inquilines T. inquilinus were collected from 10 species of Arctostaphylos, one species was collected from Comarostaphylis diversifolia, and one species was collected from Arbutus arizonica (Table 1). Our sampling scheme involved collection of T. coweni and T. inquilinus from as many host plants as possible, and, for each host plant, from several different, far-removed localities (Fig. 2). This scheme allowed us to assess the independent roles of host-plant use and geographical separation on aphid phylogenetic and phylogeographic relationships.

\section{DNA isolation, PCR and sequencing}

Aphids were crushed with a sterilized glass pipette and suspended in $0.9 \mathrm{~mL}$ Lifton buffer $(0.2 \mathrm{M}$ sucrose,
0.05 м EDTA, 0.1 м Tris, $0.5 \%$ SDS). DNA was extracted with phenol-chloroform and $70 \%$ ethanol precipitation. PCR was performed using combinations of the mitochondrial cytochrome oxidase I (COI) primers S1718 and A2191 (Simon et al., 1994). PCR product was processed using exonuclease I and shrimp alkaline phosphatase to digest single-stranded DNA and inactivate free nucleotide. Big Dye Cycle Sequencing was used to sequence a fragment $452-493 \mathrm{bp}$ long.

\section{Phylogenetic analyses}

We used maximum likelihood (ML) analysis, maximum parsimony (MP) analysis and neighbour joining (NS) to infer phylogenies for Tamalia. Pea aphid (Acyrthosiphon pisum) and wheat aphid (Schizaphis graminum)(family Aphididae) were used as outgroups.

Prior to ML analysis, we used MODELTEST (Posada $\delta$ Crandall, 1998, 2001) to infer the best model of nucleotide substitution. We conducted ML analysis, MP analysis (heuristic searching with multiple randomaddition replicates and tree bisection-reconection (TBR) branch swapping) and NJ (under a Kimura twoparameter model) in PAUP4.0b10 (Swofford, 2002). For likelihood analyses, phylogenies were also inferred using Mr Bayes 2.01 (Huelsenbeck \& Ronquist, 2002), which allows assessment of phylogeny robustness using a posteriori probabilities. In our Bayesian analysis, we 


\begin{tabular}{|c|c|c|c|}
\hline Host plant & Aphid species & Fig. 2 location & Collection site \\
\hline \multicolumn{4}{|l|}{ Gall-inducers } \\
\hline Arbutus arizonica & Tamalia morani & 8 & Santa Catalina Mts, AZ \\
\hline Comarostaphylis diversifolia & Tamalia cruzensis & 17 & Santa Cruz Island, CA \\
\hline Arctostaphylos glandulosa3 & Tamalia coweni & 24 & Mt Tamalpais, CA \\
\hline Arctostaphylos glandulosa1 & Tamalia coweni & 37 & Santa Monica Mts, CA \\
\hline Arctostaphylos glauca1 & Tamalia sp. nov. & 30 & San Bernardino Mts, CA \\
\hline Arctostaphylos glauca4 & Tamalia sp. nov. & 33 & San Gabriel Mts, CA \\
\hline Arctostaphylos glauca2 & Tamalia sp. nov. & 45 & Potrero, CA \\
\hline Arctostaphylos insularis1 & Tamalia coweni & 46 & Santa Cruz Island, CA \\
\hline Arctostaphylos patula8 & Tamalia coweni & 2 & Pea Vine Ridge, Sierra Nevada, CA \\
\hline Arctostaphylos patula1 & Tamalia coweni & 6 & Blodgett Forest, Sierra Nevada, CA \\
\hline Arctostaphylos patula6 & Tamalia coweni & 25 & Sierra Buttes, CA \\
\hline Arctostaphylos patula5 & Tamalia coweni & 29 & Trinity Alps, CA \\
\hline Arctostaphylos patula4 & Tamalia coweni & 32 & Santa Rosa Mts, CA \\
\hline Arctostaphylos pringlei4 & Tamalia dicksoni & 14 & San Bernardino Mts, CA \\
\hline Arctostaphylos pungens1 & Tamalia coweni & 13 & Santa Catalina Mts, AZ \\
\hline Arctostaphylos pungens6 & Tamalia coweni & 19 & Cuyacama Mts, CA \\
\hline Arctostaphylos pungens2 & Tamalia coweni & 27 & New York Mts, CA \\
\hline Arctostaphylos pungens4 & Tamalia coweni & 39 & Laguna Mts, CA \\
\hline Arctostaphylos tomentosa1 & Tamalia coweni & 18 & Montara Mt, CA \\
\hline Arctostaphylos tomentosa2 & Tamalia coweni & 21 & Montara Mt, CA \\
\hline Arctostaphylos uva-ursi & Tamalia coweni & 34 & Indiana Dunes Lakeshore \\
\hline Arctostaphylos viridissima1 & Tamalia coweni & 40 & Santa Cruz Island, CA \\
\hline Arctostaphylos viscida3 & Tamalia coweni & 3 & Blodgett Forest, Sierra Nevada, CA \\
\hline Arctostaphylos viscida6 & Tamalia coweni & 9 & Pea Vine Ridge, Sierra Nevada, CA \\
\hline Arctostaphylos viscida1 & Tamalia coweni & 11 & American River Forks, CA \\
\hline Arctostaphylos viscida4 & Tamalia coweni & 36 & lone, CA \\
\hline Arctostaphylos viscida8 & Tamalia coweni & 42 & S. Fork American River, CA \\
\hline Arctostaphylos viscida10 & Tamalia coweni & 44 & Quincy, CA \\
\hline \multicolumn{4}{|l|}{ Inquilines } \\
\hline Arctostaphylos glandulosa2 & Tamalia inquilinus & 10 & Santa Monica Mts, CA \\
\hline Arctostaphylos glandulosa4 & Tamalia inquilinus & 22 & Mt Tamalpais, CA \\
\hline Arctostaphylos glauca3 & Tamalia sp. nov. & 15 & San Bernardino Mts, CA \\
\hline Arctostaphylos glauca5 & Tamalia sp. nov. & 47 & San Gabriel Mts, CA \\
\hline Arctostaphylos patula9 & Tamalia inquilinus & 12 & Pea Vine Ridge, Sierra Nevada, CA \\
\hline Arctostaphylos patula7 & Tamalia inquilinus & 20 & Sierra Buttes, CA \\
\hline Arctostaphylos patula2 & Tamalia inquilinus & 26 & Blodgett Forest, Sierra Nevada, CA \\
\hline Arctostaphylos patula3 & Tamalia inquilinus & 28 & Santa Rosa Mts, CA \\
\hline Arctostaphylos pringlei3 & Tamalia sp. nov. & 35 & Santa Rosa Mts, CA \\
\hline Arctostaphylos pungens7 & Tamalia inquilinus & 4 & Cuyacama Mts, CA \\
\hline Arctostaphylos pungens5 & Tamalia inquilinus & 16 & Laguna Mts, CA \\
\hline Arctostaphylos pungens3 & Tamalia inquilinus & 31 & New York Mts, CA \\
\hline Arctostaphylos viscida2 & Tamalia inquilinus & 1 & Blodgett Forest, Sierra Nevada, CA \\
\hline Arctostaphylos viscida7 & Tamalia inquilinus & 7 & Pea Vine Ridge, Sierra Nevada, CA \\
\hline Arctostaphylos viscida5 & Tamalia inquilinus & 38 & lone, CA \\
\hline Arctostaphylos viscida9 & Tamalia inquilinus & 41 & S. Fork American River, CA \\
\hline Arctostaphylos viscida11 & Tamalia inquilinus & 43 & Quincy, CA \\
\hline
\end{tabular}

Table 1 Aphid samples used for generating the phylogenies based on mtDNA sequences. See Fig. 2 for geographical locations of collection sites. used 33000 trees inferred after stabilization of the likelihood for our a posteriori distribution, from which a $50 \%$ majority rule tree was constructed. We also tested the validity of a molecular clock, by comparing the likelihood of the best tree to the likelihood of a clockconstrained tree with the same topology.

For NJ analysis, we evaluated phylogeny robustness using 500 bootstrap replicates. MP bootstrapping was not computationally feasible due to the presence of very similar sequences for numerous samples.
As many of our samples were intraspecific, such that ancestral haplotypes may be extant, we also inferred haplotype networks using TCS (Templeton-CrandallSing) networks (Clement et al., 2000), whereby statistical parsimony is used (Templeton et al., 1992) to infer relationships between closely related haplotypes. Statistical parsimony analysis utilizes information in identical as well as differing base pairs, under a model where changes are assumed independent and equally likely at different sites. 
Fig. 2 Collection sites for Tamalia aphids. Numbers correspond to samples listed in Table 1.

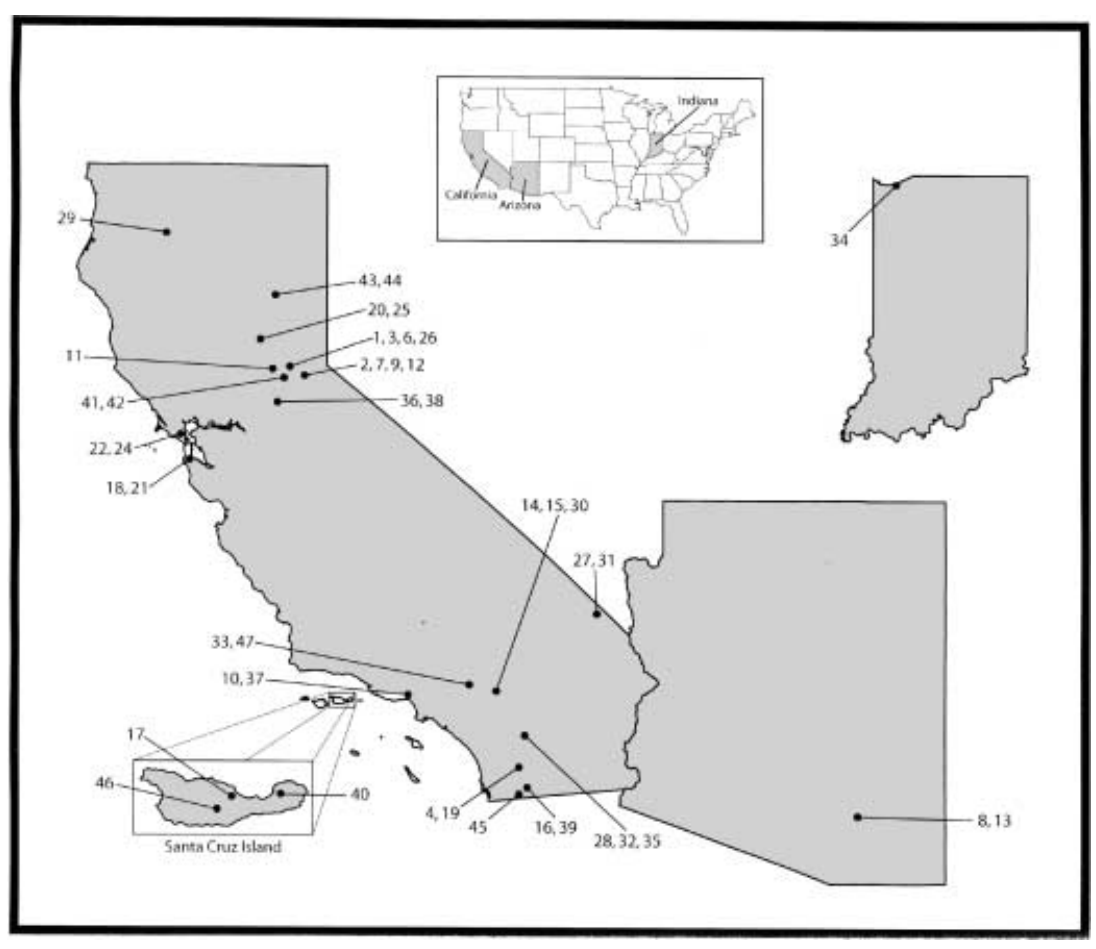

\section{Results}

\section{Data set}

The full data set comprised 452-493 base pairs for 45 samples, of which 25 were $T$. coweni, 17 were T. inquilinus, and there was one each of $T$. dicksoni, $T$. cruzensis, and T. morani. Of these 45 samples, there were nine cases of identical haplotypes (described below). Within the in group, 61 characters were parsimony-informative, most of which (50) were third codon positions. Distances within the in group ranged from 0 to $9.2 \%$.

\section{Phylogenetic analyses}

Maximum-likelihood analysis yielded two best trees (-ln likelihood 1902.52) (Fig. 3a,b). In both of these trees, the genus Tamalia was monophyletic, the galler T. coweni was paraphyletic with respect to the galler $T$. dicksoni, and the inquiline $T$. inquilinus was monophyletic and formed the sister-group to ( $T$. coweni $+T$. dicksoni). These three species on Arctostaphylos thus formed a monophyletic group. Tamalia cruzensis on $C$. diversifolia was sister-taxon to $(T$. coweni $+T$. dicksoni $+T$. inquilinus) and T. morani on Arbutus arizonica was basal to the other Tamalia.

Bayesian-ML analysis (Fig. 4) demonstrated strong support $(100 \%)$ for the monophyly of Tamalia, for the monophyly of (T. coweni + T. dicksoni) $(84 \%)$ and for the monophyly of $T$. inquilinus $(98 \%)$. However, by this analysis the relationships of these two groups with $T$. cruzensis and T. morani were unclear. The main intraspecific pattern exhibited by this analysis was a striking asymmetry in the degrees of support for the monophyly of $T$. coweni vs. T. inquilinus collected from different host plants. Thus, there was strong support for the monophyly of $T$. inquilinus on $A$. viscida, $A$. pungens and $A$. glauca, and for two monophyletic groups (although polyphyly overall) on A. patula; there was also strong support for monophyly of the $T$. inquilinus on A. glandulosa and A. pringlei. By contrast, T. coweni from different host plants exhibited strong support for monophyly (97\%) only on $A$. glauca, although three of the four samples from $A$. patula were also monophyletic. This asymmetry in resolution and support between the gallers and their inquilines was not due to the presence of gallers from four host plants (A. tomentosa, A. viridissima, $A$. insularis and $A$. uva-ursi) that were not represented among the inquilines; when the samples from these plants were omitted, degrees of resolution and support in T. coweni remained similar (results not shown).

Maximum parsimony analysis on the full data set was not computationally feasible due to the presence of identical haplotypes in $T$. coweni on A. viscida (five identical haplotypes), A. glauca (two identical), on $A$. patula, $A$. pungens and $A$. insularis (one identical, on all three plant species), and in T. inquilinus on $A$. viscida (four identical). As a result, we ran the analysis after pruning the data set such that it contained no identical haplotypes for a given aphid species on a given host plant 
(a) Maximum-likelihood tree 1

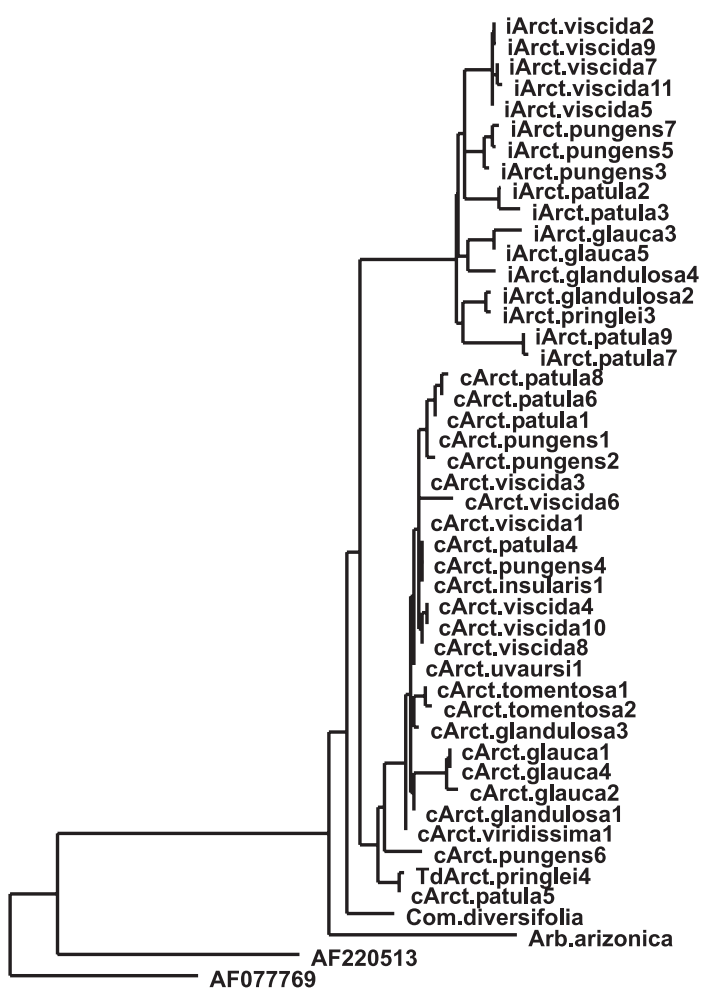

(b) Maximum-likelihood tree 2

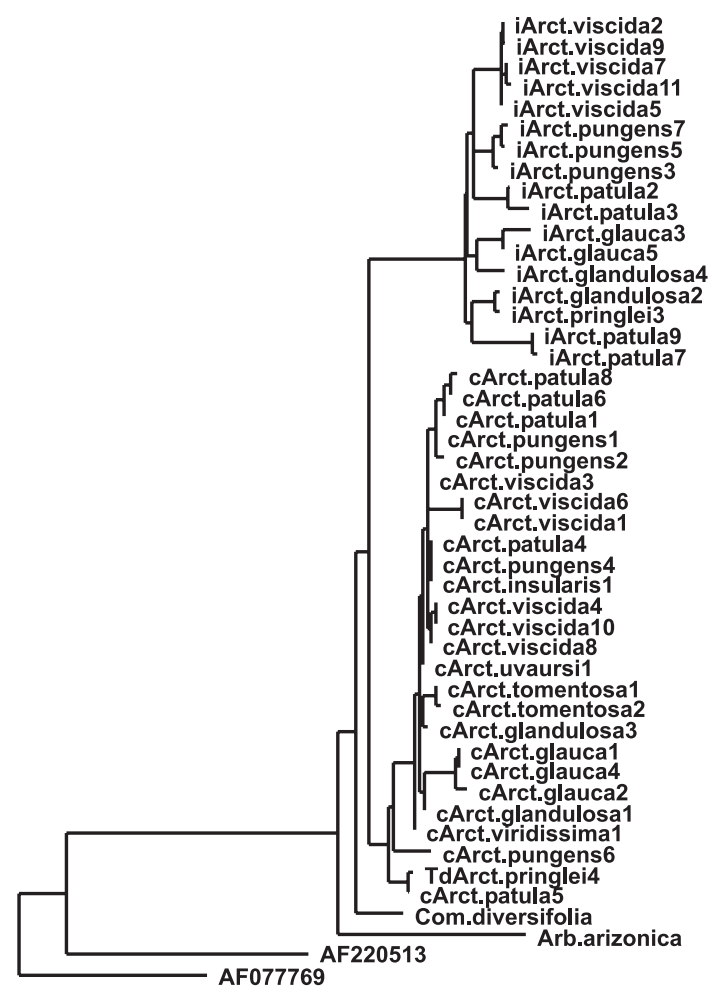

Fig. 3 Two best maximum-likelihood trees for Tamalia aphids. Taxon designation indicate: Species: ' $\mathrm{c}^{\prime}=$ T. coweni, ' $\mathrm{i}$ ' $=$ T. inquilinus, 'Td' $=$ T. dicksoni; Host plant: 'Arct' $=$ Arctostaphylos, 'Com' = Comarostaphylis, 'Arb' = Arbutus, followed by species name of host plant; Number $=$ specimen number, corresponding to numbers in Table 1 and Fig. 2.

(i.e. we removed four of the T. coweni on $A$. viscida, one of the T. coweni on A. glauca and three of the T. inquilinus on A. viscida). Parsimony analysis of this reduced data set yielded 15866 trees of length 231, and a strict consensus of these trees (Fig. 5) was similar to the ML trees, in that it showed (1) monophyly of T. inquilinus, (2) paraphyly of $T$. coweni with respect to $T$. dicksoni, (3) a basal position within the genus for T. morani on Arbutus, (4) good resolution among the $T$. inquilinus from $A$. pungens, A. glauca, A. viscida, and two monophyletic groups comprising $A$. patula, and (5) a relative lack of resolution for $T$. coweni from different host plants, in that only the samples from $A$. glauca were monophyletic on their host plant.

The NJ tree (Fig. 6) was very similar in topology to the ML trees. The main differences between the NJ tree and the ML trees were that in the NJ tree, T. cruzensis from C. diversifolia was sister-taxon to T. coweni and T. dicksoni, and the two T. coweni from $A$. tomentosa were monophyletic. Bootstrapping under NJ revealed the same general patterns as found in the ML Bayesian analysis, with strong support for: (1) monophyly of Tamalia, (2) monophyly of (T. coweni + T. dicksoni), (3) monophyly of T. inquilinus, (4) a basal position of T. morani on Arbutus within the genus, and (5) monophyly of $T$. inquilinus on each of the plants $A$. viscida, A. pungens and $A$. glauca, and for two clades on $A$. patula, but for $T$. coweni only the haplotypes from $A$. glauca forming a clear monophyletic group.

Statistical parsimony analysis also showed extremely different patterns of association between moleculargenetic relatedness and host-plant use for $T$. coweni vs. T. inquilinus (Fig. 7). Thus, for T. coweni and T. dicksoni, many pairs of haplotypes collected from different Arctostaphylos species were separated by only a single mutational step (e.g. viscida and patula, patula and pringlei, patula and glandulosa, viscida and uva-ursi) and there was only slight apparent evidence for clustering of haplotypes by host plant, for $T$. coweni on A. tomentosa, A. patula, A. glauca and $A$. glandulosa. By contrast, the T. inquilinus haplotypes formed four networks that were separated by more steps than the statistical parsimony limit. Three of these networks contained haplotypes from a single host plant, and in the fourth, largest network, haplotypes from $A$. pungens clustered together, and the haplotype on $A$. viscida was separated from haplotypes on other plants by at least nine steps. Indeed, only the two haplotypes of $T$. inquilinus on $A$. glandulosa and $A$. pringlei that were separated by two steps provided any evidence against 


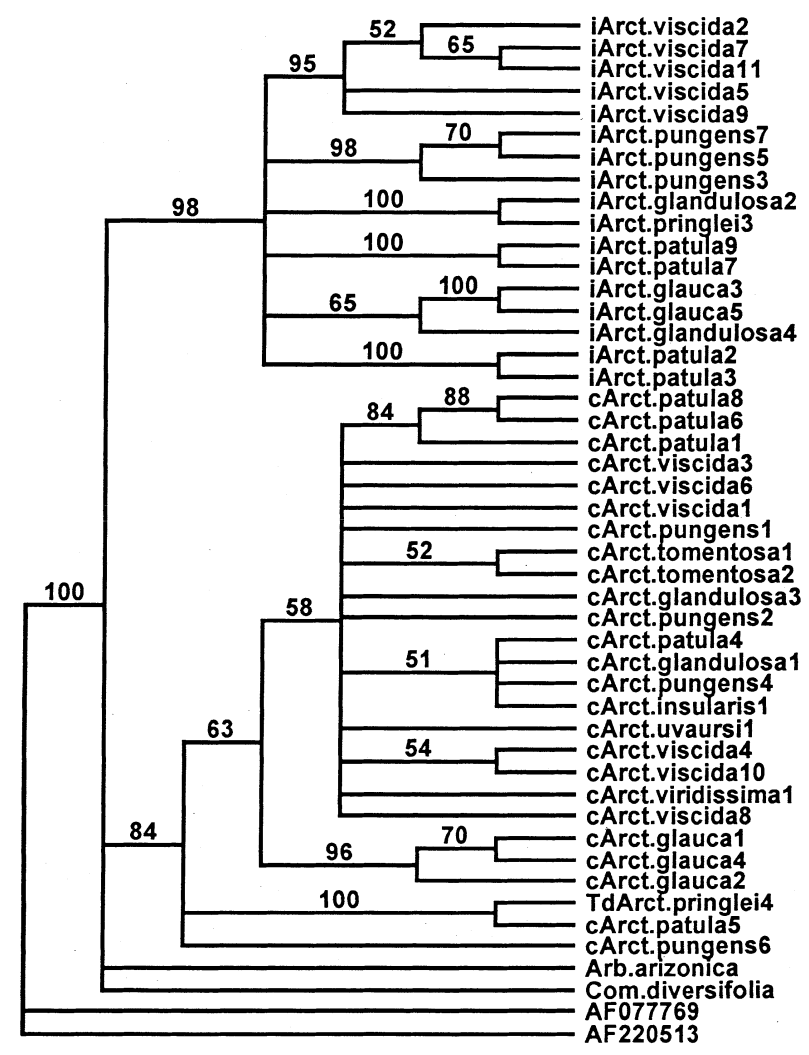

Fig. 4 Bayesian maximum-likelihood majority rule tree, inferred from 33000 a posteriori trees after convergence to a stable likelihood.

strong genetic differentiation by host plant in this species.

A molecular clock was strongly rejected for the in-group ( -2 ln likelihood difference $=279.5$, d.f. $=35$, $P<0.001$, identical haplotypes excluded). This rate variation was apparently due to an accelerated rate of molecular evolution in $T$. inquilinus compared with T. coweni: the branch lengths (internodes) within the T. inquilinus clade were 2.5-3 times longer on average than the branch lengths within $T$. coweni, and this difference was significant using patristic distances, NJ distances, and for one of the two best ML trees using ML branch lengths (Table 2 ).

\section{Discussion}

\section{Evolutionary origin of inquilines}

What is the evolutionary relationship between the host aphids and their inquilines, and how did the inquilines originate? Our ML, MP and NJ phylogenies provide strong support for the monophyly of Tamalia, the monophyly of (T. cruzensis $+T$. coweni $+T$. dicksoni + $T$. inquilinus), and the monophyly of $T$. inquilinus. Moreover, the ML tree supports a sister-taxon

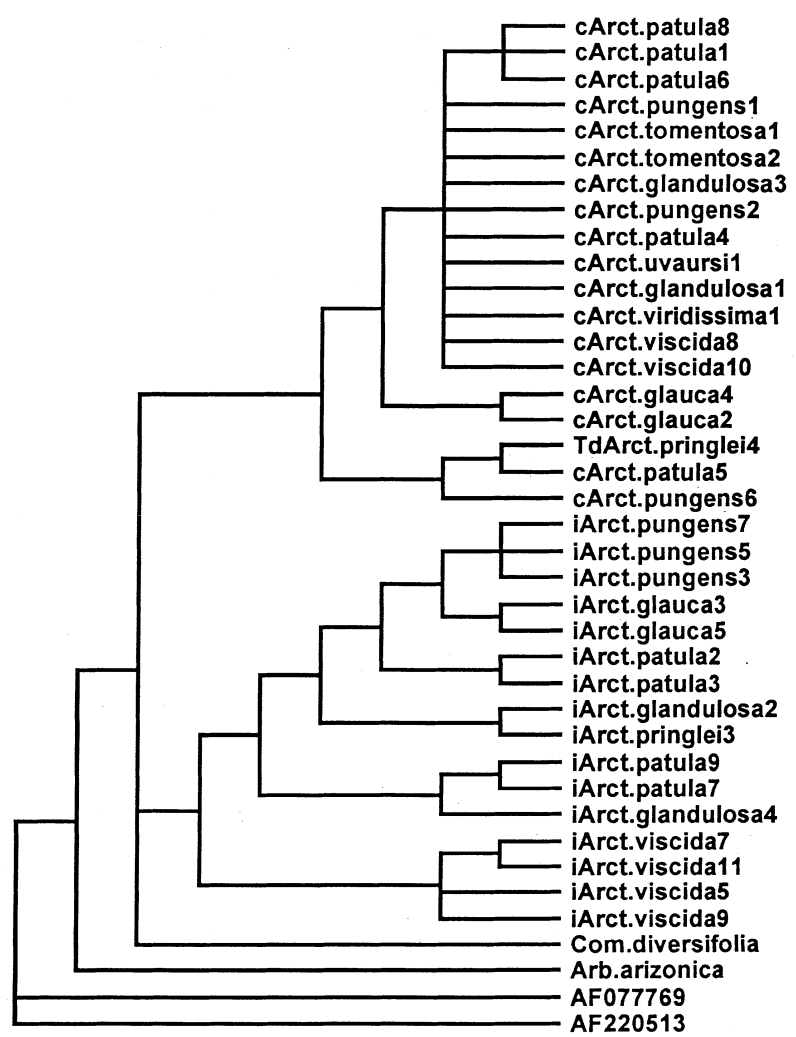

Fig. 5 Strict consensus maximum parsimony tree. Taxon designations are described in legend to Fig. 3.

relationship between $T$. inquilinus and their $T$. coweni hosts, although this relationship was not strongly supported by the Bayesian majority-rule trees, nor by the NJ tree, which put T. cruzensis as sister-taxon to T. coweni and (T. coweni $+T$. cruzensis) as the sister-group to T. inquilinus. These analyses show that the inquilines evolved once, from a gall-inducing Tamalia ancestor, and subsequently underwent their remarkable radiation primarily along host-plant lines.

Based on the natural history of Tamalia aphids, there are two possible routes to the origin of inquilinism: (1) interspecific colonization or (2) intraspecific divergence. By the interspecific colonization hypothesis, one species of gall-inducing aphid that exhibited communal galling gave rise to two species, presumably on different host plants. Upon recontact, one of the species began to colonize galls of the other, but it did not form galls on this plant, either because it arrived too late in leaf development (caused by differences in host-plant phenology), or because it was unable or prohibitively costly to form galls (e.g. caused by differences in host-plant physiology). This host-shifting, colonizing species then evolved obligate inquilinism as a consequence of selection for specialization as a gall invader, and via specialization to its newly adopted host plant. 


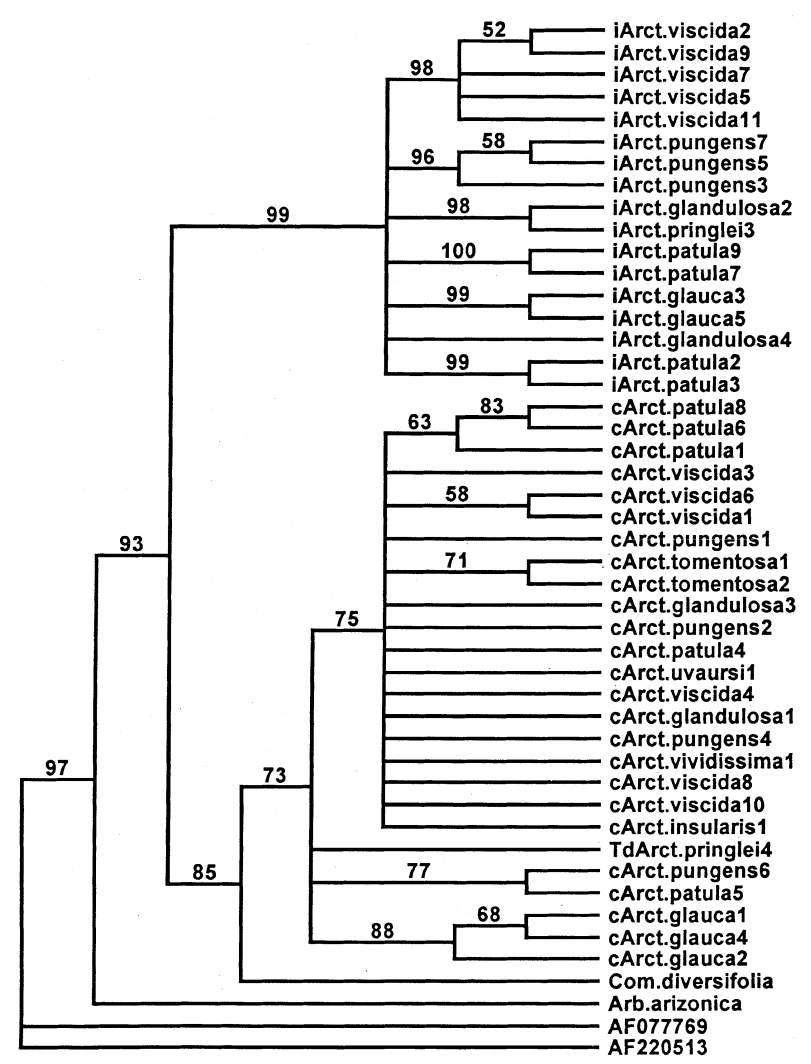

Fig. 6 Neighbour-joining bootstrap tree. Taxon designations are described in legend to Fig. 3.

There are three main lines of evidence consistent with the interspecific colonization hypothesis. First, in both Eriosoma aphids (Akimoto, 1988a,b, 1989) and Yucca moths (Pellmyr et al., 1996), obligate invaders or cheaters have also originated in conjunction with host-plant shifts by closely related species (see also Desprès \& Jaeger, 1999, for a case of parasitism arising without a host shift). These parallel cases suggest that host-plant shifting may often facilitate the origin of new life-history modes in phytophagous insects, perhaps because the host-insect species have few evolved defences against the nascent inquiline or cheater (i.e. it is invading 'defence-free space')(Crespi \& Abbot, 1999), and because a shift to a new host plant will engender a period of strong divergent selection, capable of leading to major life-history alteration (e.g. Price \& Willson, 1976; Berlocher \& Feder, 2002). Secondly, the origin of inquilines was inferred to have taken place near to the time of the split between Tamalia on Comarostaphylis and those on Arctostaphylos, such that it may have involved a host shift between these aphids on different plant genera, which would be expected to involve stronger selective effects than a within-genus switch. Thirdly, Tamalia host plants differ substantially in phenology (Munz, 1974), as do T. coweni and T. inquilinus, which suggests that, as in other cases of

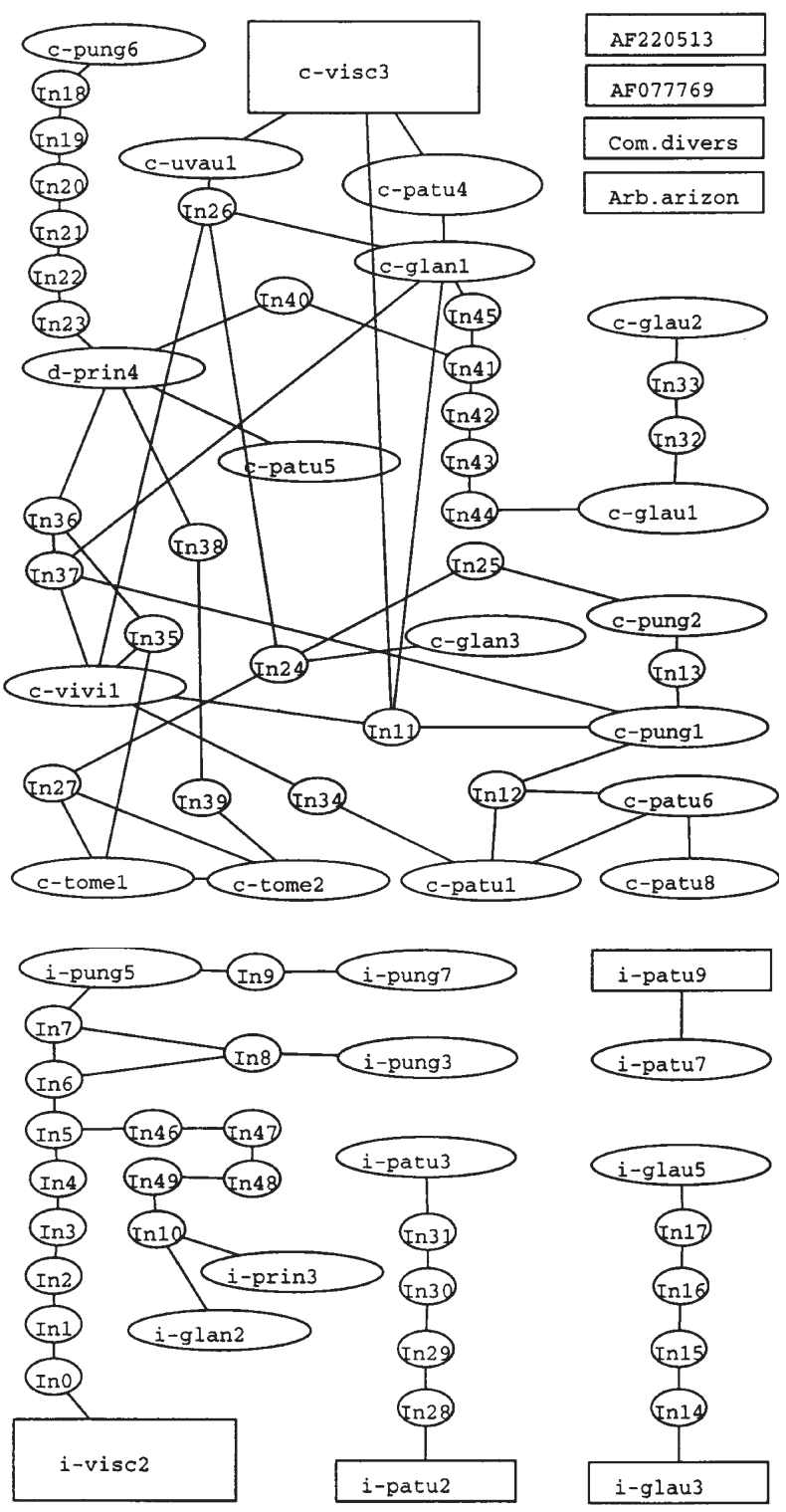

Fig. 7 TCS network. Taxon designations are described in legend to Fig. 3 and circles containing 'In' refer to inferred intermediate haplotypes. Separated subnetworks or taxa differ by greater than the statistical parsimony limit of nine steps.

speciation among phytophagous insects (Butlin, 1990; Wood et al., 1990; Knerer, 1991; Feder et al., 1993; Pellmyr et al., 1996; Romstock-Völkl, 1997; Dixon, 1998; Lin $\&$ Wood, 2002), changes in life-cycle timing may often drive the origin of reproductive isolation.

By the intraspecific divergence hypothesis, host-plant shifting was not involved in the origin of the inquilines. Instead, they evolved sympatrically with their hosts via facultative intraspecific inquilinism (i.e. communal galling) being transformed into obligate intraspecific inquilinism and finally obligate interspecific inquilinism. 
Table 2 Comparisons of branch lengths (internodes) between the Tamalia coweni clade and the T. inquilinus clade. Maximum-likelihood (ML) distances were used for the two best ML trees, patristic distances (numbers of inferred steps) were used for maximum parsimony (MP) trees and neighbour-joining (NJ) distances were used for the NJ trees. Results were qualitatively the same as regards significance values for a larger sample of the other equally parsimonious MP trees. Identical haplotypes were excluded prior to these analyses, and terminal tip branch lengths were not included in the calculations because some were undefined or of zero length.

\begin{tabular}{|c|c|c|c|c|c|}
\hline & \multicolumn{2}{|c|}{ Maximum likelihood mean $\pm \mathrm{SE}(\mathrm{N})$} & \multicolumn{2}{|c|}{ Maximum parsimony mean \pm SE $(\mathrm{N})$} & \multirow{2}{*}{$\begin{array}{l}\text { Neighbour } \\
\text { joining mean } \pm \text { SE }(N\end{array}$} \\
\hline & $\mathrm{ML}$ tree 1 & ML tree 2 & MP tree 1 & MP tree 2 & \\
\hline T. coweni & $0.005 \pm 0.001$ & $0.005 \pm 0.001(18)$ & $1.71 \pm 0.34(17)$ & $1.82 \pm 0.37(17)$ & $0.002 \pm 0.00034(26)$ \\
\hline T. inquilinus & $0.013 \pm 0.004(14)$ & $0.012 \pm 0.004(14)$ & $4.46 \pm 0.95(13)$ & $4.21 \pm 0.86(14)$ & $0.006 \pm 0.001(16)$ \\
\hline Z (Mann-Whitney U-test) & 2.58 & 1.79 & 2.44 & 2.31 & 2.23 \\
\hline$P$ & 0.0098 & 0.074 & 0.015 & 0.021 & 0.026 \\
\hline
\end{tabular}

This hypothesis is formally similar to the ideas proposed for the sympatric origin of parasitic and inquiline ant species (Wilson, 1971; Buschinger, 1986, 1990; Bourke \& Franks, 1991; see also West-Eberhard, 1986), and it entails the same difficulty in that the social, ecological or phenological bases for the necessarily strong assortative mating and divergent selection have yet to be clearly demonstrated. However, such a mode of speciation might be feasible if intraspecific inquilines were selected to emerge at ever-later dates in the season, such that they appeared after gall-makers had mated and so were temporally reproductively isolated with a concomitant loss of the ability to cause galls. Consistent with this hypothesis, inquilines are more abundant late in the season when galls are mature or abandoned. However, on some host plants, such as A. glauca, the gall-inducers and inquilines frequently co-occur early in the season, which argues against a phenological shift unless this overlap in life history, or use of such host plants, evolved after the inquilines arose.

By both the interspecific colonization hypothesis and the intraspecific divergence hypothesis, the habit of communal galling serves as a crucial pre-adaptation to inquilinism. Communal intraspecific gall habitation creates conditions favouring inquilinism because, unlike in other galling insects that exhibit extreme aggression among foundresses (Whitham, 1979; Crespi, 1992; Ngakan \& Yukawa, 1996; Akimoto \& Yamaguchi, 1997), Tamalia foundresses tolerate one another within their newly forming gall. Indeed, both intraspecific communal galling, and non-aggressive interspecific cohabitation of hosts and inquilines, are known in aphids only from this genus. Analogously, the presence of larvae from multiple females in the communal galls formed by some other gall-forming insects may also have facilitated the evolution of interspecific inquilinism (Ronquist, 1994; Yang \& Mitter, 1994; Ronquist \& Liljeblad, 2001; Stone et al., 2002; Yang et al., 2001).

The above-mentioned ideas could be tested further via: (1) conducting experimental, interspecific host-plant switches, to determine if $T$. coweni that arrive relatively late at a host plant are more likely to act as intraspecific inquilines, or, apparently, interspecific inquilines in the case of A. glauca vs. other Arctostaphylos species, (2) quantification of phenological overlap between $T$. coweni and T. inquilinus on different Arctostaphylos species, and (3) testing the sympatric speciation scenario using methods outlined in Berlocher \& Feder (2002). Such tests should improve our understanding of one of the most important types of life-history transitions in insects and other animals, from resource generation to exploitation.

\section{Host-plant specificity of gallers and inquilines}

Our phylogenetic analyses indicate that the gall-inducing species $T$. coweni is substantially less differentiated by host-plant than its inquiline $T$. inquilinus. Thus, for $T$. coweni only the samples from A. glauca formed a strongly supported monophyletic group. Although the samples from $A$. viscida, $A$. tomentosa, and from three of the four samples from $A$. patula, were each monophyletic on the host plant, bootstrap or Bayesian support was weak for these nodes, and the TCS network showed that all of the samples were only one to three mutational steps away from samples on a different host plant. Moreover, field experiments demonstrate that $T$. coweni winged females from $A$. patula will larviposit on $A$. viscida, and vice versa (D. Miller, unpublished data), which also is consistent with oligophagy, or very weak differentiation, between $T$. coweni on plants other than A. glauca.

In contrast to the general lack of strong host-plant association in T. coweni, for T. inquilinus the samples from A. glauca, A. pungens and A. viscida were each clearly monophyletic on their host plant, and the four samples from $A$. patula formed two separate monophyletic groups of two. Indeed, the only evidence for deviation from strict host-plant specificity in these inquilines is the polyphyly of the two samples from A. glandulosa, and the observation that one sample from $A$. glandulosa was only two mutational steps away from a sample from $A$. pringlei in the TCS network.

The degree of mitochondrial divergence between hostplant associated groups of T. inquilinus was over $2 \%$ in all 
cases, which is consistent with an absence of gene flow between them and possible sibling species status. Similarly, for T. coweni, the divergences between samples on A. glauca, and samples from all of the other Arctostaphylos host plants, were all over $1.5 \%$, which is also consistent with sibling species status. Further testing of hypotheses concerning sibling species vs. host race or polyphagous status requires data on gene flow, the genetic basis of adaptation, or mating experiments (Berlocher \& Feder, 2002; Ferguson, 2002). Whatever the results of such studies, our data show conclusively that $T$. inquilinus shows a substantially higher degree of mitochondrial differentiation along host-plant lines than does its host aphid $T$. coweni. Given the close ecological similarities between these two species, comparison between the two clades comprising them should help in elucidating the conditions under which specificity of insects to host plants evolves. Indeed, these and clades of other phytophagous insects showing variable degrees of host-plantassociated differentiation (e.g. Roininen et al., 1993; Downie et al., 2001; Nyman, 2002) should provide especially useful systems for analysing the processes leading to speciation.

We propose three non-exclusive hypotheses to help explain the higher degree of host-plant differentiation in $T$. inquilinus than in T. coweni. First, rates of gene flow may be lower among populations of $T$. inquilinus, because winged asexual females of this species are rare and the primary mode of dispersal in this species is via the sexual generation at the end of the growing season. By contrast, in $T$. coweni both winged females and sexual aphids are common and can disperse. Moreover, T. coweni may be under stronger selection to disperse, because these aphids need find only an appropriate host plant to gall, whereas $T$. inquilinus must find a host plant that is already occupied by the gall-inducers. Under these conditions, staying in the same patch of the host plant, which has supported $T$. coweni in the previous generation, may be strongly favoured.

Secondly, inquilines, like parasites, should exhibit smaller population sizes due to their reliance on resources created by their hosts (Dowton \& Austin, 1995; Page et al., 1998; Castro et al., 2002). Such small population sizes should engender enhanced founder effects, and stronger demic structure leading to local population subdivision. This hypothesis predicts higher rates of molecular evolution in $T$. inquilinus than in T. coweni, which is supported by our molecular-clock analyses and by comparisons of branch lengths (Table 2).

These data, together with previous studies (Dowton $\delta$ Austin, 1995; Castro et al., 2002), show that faster molecular-evolutionary rates in parasites or inquilines, than in hosts, occur across a broad range of insect taxa, which implies that such rate differences and their causes are of general importance to the evolution of such systems. In T. inquilinus, a hypothesis of lower effective population size leading to accelerated mtDNA substitu- tion rates could be tested more directly using phylogenybased coalescent methods (e.g. Beerli \& Felsenstein, 2001 ), or by measuring gene diversity at codominant loci.

The above mentioned hypotheses involve more local genetic differentiation in $T$. inquilinus than in $T$. coweni, which would not necessarily occur among host-plant species unless there were selection for host-plant specialization. A third hypothesis for the higher levels of specialization in T. inquilinus is that they are more closely adapted to specific host-plant species, physiologically, morphologically, behaviourally or phenologically. The main differences between $T$. coweni and T. inquilinus relevant to their host plants involve life cycle phenology: most important, T. inquilinus females have a narrower window of opportunity to establish themselves within galls, such that shifting between host plants that differ in their timing of leaf production may be considerably more difficult. Phenological effects are also implicated in the differentiation of both $T$. coweni and T. inquilinus on A. glauca, as this host plant exhibits earlier flowering (December-March), and presumably earlier leaf flushes, than A.glandulosa (January-April), A. viscida and A. pringlei (Febuary-April) or A. patula (April-June) (Munz, 1974).

The evolution of host races in other insects is, in general, marked by a relatively intimate association between the insects and the plant, involving galling, internal feeding by larvae, tight synchronization of life cycles, tendency to feed on a single host plant, and mating and oviposition on the host (Berlocher $\&$ Feder, 2002; Drès \& Mallett, 2002). As inquilines, T. inquilinus are subject to such host-related selection not only from their gall-inducing $T$. coweni hosts, but also from their host plants. As a result, they are expected to exhibit a higher level of host-related adaptation, which should lead more readily to specialization (Jaenike, 1990; Whitlock, 1996; Kawecki, 1998; Berlocher \& Feder, 2002; Nosil et al., 2002; see also Kindlemann \& Dixon, 1994; Guldemond \& Mackenzie, 1994; Mackenzie \& Guldemond, 1994; Dixon, 1998 on the evolution of specialization in aphids).

\section{Diversification of Tamalia on Arbutoideae}

Although the gall-inducing Tamalia on Arctostaphylos do not exhibit strong host-plant specificity, there is a notable pattern in Tamalia host-plant use at the genus level. Thus, T. morani, the most-basal species, is found on Arbutus, and T. cruzensis, which is sister-taxon to the species on Arctostaphylos-inhabiting species (T. coweni + $T$. inquilinus $+T$. dicksoni) in the ML trees, is found on Comarostaphylis. This higher-level phylogenetic pattern in aphid host-plant use matches the phylogeny of the plant genera: Arbutus is inferred as basal and Comarostaphylis is sister-taxon to Arctostaphylos (Hileman et al., 2001). This coincident pattern would support cospeciation at the plant genus level if the ages of the relevant inferred cospeciation events were similar for the aphids and 
plants. According to Hileman et al. (2001), fossil data indicate that the genus Arbutus is in the order of 100-240 million years old, but the presence of this genus in North America may be much more recent (as late as about 20 million years ago), and the genera Arctostaphylos and Comarostaphylis, which were derived from within the genus Arbutus, are no younger than about 15 million years old. Tamalia morani on Arbutus has diverged a maximum of $9.5 \%$ from other Tamalia, which corresponds to roughly 10 million years under an insect COI clock (Brower, 1994; Juan et al., 1995, 1996), and T. cruzensis from Comarostaphylis has diverged a maximum of $7.2 \%$ from Tamalia on Arctostaphylos, which corresponds to roughly 5 million years. Taken together, this evidence suggests that unless the genus Tamalia has an unusually slow rate of mtDNA evolution, it is too recent to have cospeciated with their host plants, at least not at the genus level. Instead, this genus may initially have colonized Arbutus, presumably host-shifting from some other plant, and later shifted to Arctostaphylos and Comarostaphylis that were already extant in western North America. This hypothesis can be tested further by collecting and sequencing Tamalia from other species of Arbutus, Comarostaphylis and Arctostaphylos, which may drive their inferred date of origin back to a time more compatible with the evolutionary chronology of their host plants. By contrast, the possibility remains that T. inquilinus is cospeciating with its Arctostaphylos hosts, as they have both apparently diversified primarily over the past several million years. Testing this idea will require more complete and robust phylogenies for both the plants and the $T$. inquilinus aphids.

\section{Acknowledgments}

We are grateful to C. Ames, C. On and M. VanKoeveringe for technical help, and we thank NSERC for financial support. M. Hedin and D. Voegtlin kindly provided Tamalia samples; N. Moran and M. Vasey indicated useful collecting localities. Lodging and access to Tamalia populations were provided by the University of California Natural Reserve System, UCSB Santa Cruz Island Reserve; the UC Riverside Philip L. Boyd Deep Canyon Desert Research Center and UC Riverside Granite Mountains Reserve; UCLA Stunt Ranch Santa Monica Mountains Reserve; and the UC Berkeley Blodgett Forest Research Station. J. Fischer and P. Ullmann assisted greatly with the figures. DGM was supported by a Trinity University Summer Research Stipend.

\section{References}

Abrahamson, W.G., Brown, J.M., Roth, S.K., Sumerford, D.V., Horner, J.D., Hess, M.D., How, S.T., Craig, T.P., Packer, R.A. \& Itami, J.K. 1994. Gallmaker speciation: an assessment of the roles of host-plant characters, phenology, gallmaker competition, and natural enemies. In: The Ecology and Evolution of Gall-
Forming Insects (P. W. Price, W. J. Mattson \& Y. N. Baranchikov, eds), pp. 208-222. US Department of Agriculture, St. Paul, MN, USA.

Akimoto, S. 1988a. The evolution of gall parasitism accompanied by a host shift in the gall aphid, Eriosoma yangi (Homoptera: Aphidoidea). Biol. J. Linn. Soc. 35: 297-312.

Akimoto, S. 1988b. Competition and niche relationships among Eriosoma aphids occurring on the Japanese elm. Oecologia 75: $44-53$.

Akimoto, S. 1989. Gall-invading behavior of Eriosoma aphids (Homoptera: Pemphigidae) and its significance. Jpn. J. Ent. 57: 210-220.

Akimoto, S. \& Yamaguchi, Y. 1997. Gall usurpation by the gallforming aphid, Tetraneura sorini (Insecta: Homoptera). Eth. Ecol. Evol. 9: 159-168.

Beerli, P. \& Felsenstein, J. 2001. Maximum likelihood estimation of a migration matrix and effective population sizes in $\mathrm{n}$ subdivided populations by using a coalescent approach. Proc. Natl. Acad. Sci. USA 98: 4563-4568.

Berlocher, S.H. \& Feder, J.L. 2002. Sympatric speciation in phytophagous insects: moving beyond controversy? Ann. Rev. Entomol. 47: 773-815.

Bourke, A.F.G. \& Franks, N.R. 1991. Alternative adaptations, sympatric speciation and the evolution of parasitic, inquiline ants. Biol. J. Linn. Soc. 43: 155-178.

Brower, A.V.Z. 1994. Rapid morphological radiation and convergence among races of the butterfly Heliconius erato inferred from patterns of mitochondrial DNA evolution. Proc. Nat. Acad. Sci. USA 91: 6491-6495.

Burckhardt, D. \& Basset, Y. 2000. The jumping plant-lice (Hemiptera, Psylloidea) associated with Schinus (Anacardiaceae): systematics, biogeography and host plant relationships. J. Nat. Hist. 34: 57-155.

Buschinger, A. 1986. Evolution of social parasitism in ants. Trends Ecol. Evol. 1: 155-160.

Buschinger, A. 1990. Sympatric speciation and radiative evolution of socially parasitic ants - heretic hypotheses and their factual background. Zeits. für Syst. und Evol. 28: 241-260.

Bush, G.L. \& Smith, J.J. 1997. The sympatric origins of phytophagous insects. In: Vertical Food Web Interactions (K. Dettner, G. Bauer \& W. Völkl, eds), pp. 21-38. Springer-Verlag, Berlin.

Butlin, R.K. 1990. Divergence in emergence time of host races due to differential gene flow. Heredity 65: 47-50.

Carpenter, J.M., Strassmann, J.E., Turillazzi, S., Hughes, C.R., Solis, C.R. \& Cervo, R. 1993. Phylogenetic relationships among paper wasp social parasites and their hosts (Hymenoptera:Vespidae: Polistinae). Cladistics 9: 129-146.

Castro, L. R., Austin, A.D. \& Dowton, M. 2002. Contrasting rates of mitochondrial molecular evolution in parasitic Diptera and Hymenoptera. Mol. Biol. Evol. 19: 1100-1113.

Clement, M., Posada, D. \& Crandall, K.A. 2000. TCS: a computer program to estimate gene genealogies. Mol. Ecol. 9: 1657-1659.

Crespi, B.J. 1992. The behavioral ecology of Australian gall thrips. J. Nat. Hist. 26: 769-809.

Crespi, B. \& Abbot, P. 1999. The behavioral ecology and evolution of kleptoparasitism in Australian gall thrips. Fla. Entomol. 82: 147-164.

Desprès, L. \& Jaeger, N. 1999. Evolution of oviposition strategies and speciation in the globeflower flies Chiastocheta species (Anthomyiidae). J. Evol. Biol. 12: 822-831.

Dixon, A.F.G. 1998. Aphid Ecology: An Optimization Approach, 2nd edn. Chapman $\&$ Hall, London. 
Downie, D.A., Fisher, J.R. \& Granett, J. 2001. Grapes, galls, and geography: the distribution of nuclear and mitochondrial DNA variation across host-plant species and regions in a specialist herbivore. Evolution 55: 1345-1362.

Dowton, M. \& Austin, A.D. 1995. Increased genetic diversity in mitochondrial genes is correlated with the evolution of parasitism in the Hymenoptera. J. Mol. Evol. 41: 958-965.

Drès, M. \& Mallet, J. 2002. Host races in plant-feeding insects and their importance in sympatric speciation. Phil. Trans. $R$. Soc. Lond. B357: 471-492.

Farrell, B. \& Mitter, C. 1990. Phylogenesis of insect/plant interactions: have Phyllobrotica leaf beetles (Chrysomelidae) and the Lamiales diversified in parallel? Evolution 44: 13891403.

Farrell, B. \& Mitter, C. 1998. The timing of insect/plant diversification: Might Tetraopes (Coleoptera: Cerambycidae) and Asclepias (Asclepiadaceae) have co-evolved? Biol. J. Linn. Soc. 63: 553-577.

Feder, J.L., Hunt, T.A. \& Bush, L. 1993. The effects of climate, host plant phenology and host fidelity on the genetics of apple and hawthorn infesting races of Rhagoletis pomonella. Ent. Exp. App. 69: 117-135.

Ferguson, J.W.H. 2002. On the use of genetic divergence for identifying species. Biol. J. Linn. Soc. 75: 509-516.

Gaston, K.J., Reavey, D. \& Valladares, G.R. 1992. Intimacy and fidelity: internal and external feeding by the British microlepidoptera. Ecol. Ent. 17: 86-88.

Guldemond, J.A. \& MacKenzie, A. 1994. Sympatric speciation in aphids. I. Host race formation by escape from gene flow. In: Individuals, Populations and Patterns in Ecology (S. R. Leather, A. D. Watt, N. J. Mills \& K. F. A. Walters, eds), pp. 367-378. Intercept Ltd., Andover.

Herre, E.A., Machado, C.A., Bermingham, E., Nason, J.D., Windsor, M., McCafferty, S.S., Van Houten, W. \& Bachmann, K. 1996. Molecular phylogenetics of figs and their pollinator wasps. J. Biogeogr. 23: 521-530.

Hileman, L.C., Vasey, M.C. \& Parker, T.V. 2001. Phylogeny and biogeography of the Arbutoideae (Ericaceae): implications for the Madrean-Tethyan Hypothesis. Syst. Bot. 26: 131-143.

Huelsenbeck, J.P. \& Ronquist, F. 2002. MrBayes: A program for the Bayesian inference of phylogeny. [WWW document] URL http://morphbank.ebc.uu.se/mrbayes/manual.pdf

Ikino, T., Davies, S.J., Tada, H., Hieda, Y., Inoguchi, M., Itioka, T., Yamane, S. \& Inoue, T. 2001. Cospeciation of ants and plants. Ecol. Res. 16: 787-793.

Jaenike, J. 1990. Host specialization in phytophagous insects. Ann. Rev. Ecol. Syst. 21: 243-273.

Janz, N. \& Nylin, S. 1998. Butterflies and plants: a phylogenetic study. Evolution 52: 486-502.

Jones, R.W. 2001. Evolution of the host plant associations of the Anthonomus grandis species group (Coleoptera: Curculionidae): phylogenetic tests of various hypotheses. Ann. Entomol. Soc. Am. 94: 51-58.

Juan, C., Oromi, P. \& Hewitt, G.M. 1995. Mitochondrial DNA phylogeny and sequential colonization of the Canary Islands by darkling beetles of the genus Pimelia (Tenebrionidae). Proc. R. Soc. Lond. B 261: 173-180.

Juan, C., Oromi, P. \& Hewitt, G.M. 1996. Phylogeny of the genus Hegeter (Tenebrionidae, Coleoptera) and its colonization of the Canary Islands deduced from cytochrome oxidase I mitochondrial DNA sequence. Heredity 76: 392-403.
Kawecki, T.J. 1998. Red queen meets Santa Rosalia: arms races and the evolution of host specialization in organisms with parasitic lifestyles. Am. Nat. 152: 635-651.

Kindlmann, P. \& Dixon, A.F.G. 1994. Evolution of host range in aphids. Eur. J. Ent. 91: 91-96.

Knerer, G. 1991. Spontaneous speciation through an overwintering change in a sawfly. Naturwiss. 78: 328-330.

Lin, C.P. \& Wood, T.K. 2002. Molecular phylogeny of the North American Enchenopa binotata (Homoptera: Membracidae) species complex. Ann. Entomol. Soc. Am. 95: 162-171.

Lopez-Vaamonde, C., Rasplus, J.V., Weiblen, G.D. \& Cook, J.M. 2001. Molecular phylogenies of fig wasps: partial cocladogenesis of pollinators and parasites. Mol. Phyl. Evol. 21: 55-71.

Lowe, R.M. \& Crozier, R.H. 1997. The phylogeny of bees of the socially parasitic Australian genus Inquilina and their Exoneura hosts (Hymenoptera, Anthophoridae). Insectes Soc. 44: 409414.

Machado, C.A., Herre, E.A., McCafferty, S. \& Bermingham, E. 1996. Molecular phylogenies of fig pollinating and nonpollinating wasps and the implications for the origin and evolution of the fig-fig wasp mutualism. J. Biogeogr. 23: 531542.

MacKenzie, A. \& Guldemond, J.A. 1994. Sympatric speciation in aphids. II. Host ace formation in the face of gene flow. In: Individuals, Populations and Patterns in Ecology (S. R. Leather, A. D. Watt, N. J., Mills, \& K. F. A. Walters, eds), pp. 379-395. Intercept Ltd., Andover.

Mani, M.S. 1964. Ecology of Plant Galls. W. Junk, The Hague.

Miller, D.G. 1998a. Life history, ecology and communal gall occupation in the manzanita leaf-gall aphid, Tamalia coweni (Cockerell) (Homoptera: Aphididae). J. Nat. Hist. 32: 351-366.

Miller, D.G. 1998b. Consequences of communal gall occupation and a test for kin discrimination in the aphid Tamalia coweni. Behav. Ecol. Sociobiol. 43: 95-103.

Miller, D.G. \& Sharkey, M.J. 2000. An inquiline species of Tamalia co-occurring with Tamalia coweni (Homoptera: Aphididae). Pan-Pacific Entomol. 76: 77-86.

Mitter C. \& Farrell, B. 1991. Macroevolutionary aspects of insect/plant relationships. In: Insect/plant Interactions (E. Bernays, ed.), Vol. 3, pp. 35-78. CRC Press, Boca Raton.

Mitter, C., Farrell, B. \& Wiegmann, B. 1988. Phylogenetic study of adaptive zones: has phytophagy promoted insect diversification? Am. Nat. 132: 107-128.

Munz, P. A. 1974. A Flora of Southern California. University of California Press, Berkeley.

Ngakan, P.O. \& Yukawa, J. 1996. Gall site preference and intraspecific competition of Neothoracaphis yanonis (Homoptera: Aphididae). App. Ent. Zool. 31: 299-310.

Nosil, P., Crespi, B.J. \& Sandoval, C.P. 2002. Host-plant adaptation drives the parallel evolution of reproductive isolation. Nature 417: 440-443.

Nyman, T. 2002. The willow bud galler Euura mucronata Hartig (Hymenoptera: Tenthredinidae): one polyphage or many monophages? Heredity 88: 288-295.

Page, R.D.M., Lee, P.L.M., Becher, S.A., Griffiths, R. \& Clayton, D.H. 1998. A different tempo of mitochondrial DNA evolution in birds and their parasitic lice. Mol. Phyl. Evol. 9: 276-293.

Pellmyr, O., Leebens-Mack, J. \& Huth, C.J. 1996. Nonmutualistic yucca moths and their evolutionary consequences. Nature 380: 155-156.

Posada, D. \& Crandall, K.A. 1998. Modeltest: Testing the model of DNA substitution. Bioinformatics 14: 817-818. 
Posada, D. \& Crandall, K.A. 2001. Selecting the best-fit model of nucleotide substitution. Syst. Biol. 50: 580-601.

Price, P.W. 1980. The Evolutionary Biology of Parasites. Princeton University Press, Princeton.

Price, P.W. \& Roininen, H. 1993. Adaptive radiation in gall induction. In: Sawfly Life History Adaptations to Woody Plants (M. R. Wagner \& K. F. Raffa, eds), pp. 229-257. Academic Press, New York.

Price, P.W. \& Willson, M.F. 1976. Some consequences for a parasitic herbivore, the milkweed longhorn beetle,Tetraopes tetraophthalmus, of a host-plant shift from Asclepias syriaca to A. verticillata. Oecologia 25: 331-340.

Remaudière, G. \& Remaudière, M. 1997. Catalogue des Aphididae du Monde. Homoptera Aphidoidea. INRA, Paris.

Roderick, G.K. 1997. Herbivorous insects and the Hawaiian silversword alliance: coevolution or cospeciation? Pacific Science 51: 440-449.

Roderick, G.K. \& Metz, E.C. 1997. Biodiversity of planthoppers (Hemiptera: Delphacidae) on the Hawaiian silversword alliance: effects on host plant phylogeny and hybridization. Memoirs of the Museum of Victoria 56: 393-399.

Roininen, H., Vuorinen, J., Tahvanainen, J. \& Julkunen-Tiitto, R. (1993). Host preference and allozyme differentiation in shoot galling sawfly, Euura atra. Evolution 47: 300-308.

Romstock-Völkl, M. 1997. Host race formation in Tephritis conura determinants from three trophic levels. In: Vertical Food Web Interactions: evolutionary patterns and driving forces (K. Dettner, G. Bauer \& W. Völkl, eds), pp. 21-38. SpringerVerlag, Berlin.

Ronquist, F. 1994. Evolution of parasitism among closely related species: phylogenetic relationships and the origin of inquilinism in gall wasps (Hymenoptera, Cynipidae). Evolution 48: 241-266.

Ronquist, F. \& Liljeblad, J. 2001. Evolution of the gall wasp-host plant association. Evolution 55: 2503-2522.

Ronquist, F. \& Nylin, S. 1990. Process and pattern in the evolution of species associations. Syst. Zool. 39: 323-344.

Schluter, D. 2000. The Ecology of Adaptive Radiation. Oxford University Press, Oxford.

Simon, C., Frati, F., Flook, P., Beckenbach, A., Crespi, B.J. \& Liu, H. 1994. Evolution, weighting and phylogenetic utility of mitochondrial gene sequences and a compilation of conserved polymerase chain reaction primers. Ann. Entomol. Soc. Am. 87: 651-701.

Stone, G.N., Schönrogge, K., Atkinson, R.J., Bellido, D. \& PujadeVillar, J. 2002. The population biology of oak gall wasps (Hymenoptera: Cynipidae). Ann. Rev. Entomol. 47: 633-668.

Swofford, D.L. 2002. PAUP*. Phylogenetic Analysis Using Parsimony (*and Other Methods). Version 4. Sinauer Associates, Sunderland, MA, USA.

Templeton, A.R., Crandall, K.A. \& Sing, C.F. 1992. A cladistic analysis of phenotypic associations with haplotypes inferred from restriction endonuclease mapping and DNA sequence data. III. Cladogram estimation. Genetics 132: 619-633.

Von Dohlen, C.D. \& Moran, N.A. 2000. Molecular data supports a rapid radiation of aphids in the Cretaceous and multiple origins of host alternation. Biol. J. Linn. Soc. 71: 689717.

West-Eberhard, M.J. 1986. Alternative adaptations, speciation and phylogeny (a review). Proc. Natl. Acad. Sci. USA 83: 13881392.

Whitham, T.G. 1979. Territorial behavior of Pemphigus gall aphids. Nature 279: 324-325.

Whitlock, M.C. 1996. The red queen beats the jack-of-all-trades: the limitations on the evolution of phenotypic plasticity and niche breadth. Am. Nat. 148: S65-S77.

Wilson, E.O. 1971. The Insect Societies. Belknap Press of Harvard University Press, Cambridge, MA, USA.

Wood, T.K., Olmstead, K.L. \& Guttman, S.I. 1990. Insect phenology mediated by host-plant water relations. Evolution 44: 629-636.

Yang, M. \& Mitter, C. 1994. Biosystematics of hackberry psyllids (Pachypsylla) and the evolution of gall and lerp formation in psyllids (Homoptera: Psylloidea): A preliminary report. In: The Ecology and Evolution of Gall-Forming Insects (P. W. Price, W. J. Mattson \& Y. N. Baranchikov, eds), pp. 172-185. US Department of Agriculture, St Paul, MN, USA.

Yang, M., Mitter, C. \& Miller, D.R. 2001. First incidence of inquilinism in gall-forming psyllids, with a description of the new inquiline species (Insecta, Hemiptera, Psylloidea, Psyllidae, Spondyliaspidinae). Zoologica Scripta 30: 97-113.

Received 11 September 2002; revised 13 December 2002; accepted 3 February 2003 